\title{
Teacher Candidate Views on the Use of YouTube for Educational Purposes
}

\author{
Ayşegül Nacak ${ }^{{ }^{*}}$ \\ (iD) 0000-0002-9298-8591
}

\section{Başak Bağlama ${ }^{2}$}

(iD) 0000-0001-7982-8852

\author{
Burak Demir ${ }^{3}$ \\ (iD) 0000-0001-5666-359X \\ 1 Department of Communication, Faculty of Communication and Media, Girne American University, North Cyprus, Mersin \\ 10, TURKEY \\ ${ }^{2}$ Department of Special Education, Atatürk Faculty of Education, Near East University, North Cyprus, Mersin 10, TURKEY \\ ${ }^{3}$ Research Assistant, Atatürk Faculty of Education, Near East University, North Cyprus, Mersin 10, TURKEY \\ *Corresponding author: aysegulnacak1985@hotmail.com
}

Citation: Nacak, A., Bağlama, B., \& Demir, B. (2020). Teacher Candidate Views on the Use of YouTube for Educational Purposes. Online Journal of Communication and Media Technologies, 10(2), e202003. https://doi.org/10.29333/ojcmt/7827

\section{ARTICLE INFO}

Received: 17 Feb 2020

Accepted: 5 Mar 2020

\section{ABSTRACT}

This study aims to determine the views of teacher candidates on the use of YouTube for educational purposes. Study group consisted of 14 teacher candidates studying at faculty of education.In this research where quantitative research method is used, a semi-structured interview form developed by the researchers within the purpose of the research was used as a data collection tool. According to the results, it was determined that teacher candidates generally found YouTube as an appropriate educational material for different lessons, they think that YouTube promotes permanence and reinforces learning. In addition, teacher candidates stated that YouTube might lead to addiction to technology and lack of eye contact during lesson might be regarded as one of the disadvantages of using YouTube. Teacher candidates suggested that necessary descriptions for teachers on how to use YouTube for educational purposes can motivate teachers to use YouTube during lectures.

Keywords: education, video, YouTube, teacher candidates, views

\section{INTRODUCTION}

Great advancements in technology lead to many facilities in educators and researchers to enhance individuals' learning more effectively. Today, students grow up in multimedia world and they are enhanced with technology forming a digital generation. As one of the most prevalently used instructional technologies, videos are effective communication and learning tools which prompt both visual and hearing senses.Videos are multimedia environment applications in which both animation and audio are played together (Mardis, 2009). According to Chen and Wu (2015), videos are communication tools in which attact learners' attention towards learning, address both eyes and ear and have a high level of effectiveness in learning. In addition, they are effective instructional materials which enable to create an independent learning environment in terms of individual learning opportunity, time and location.

Use of videos in teaching-learning environments is considered as a pedagogical tool and a combination of theory and application. Use of videos as instructional materials has various effects involving cognitive benefits (learning, memorizing), psychological benefits (motivation, learnig attitude) and visualization of knowledge (Gaudin \& Chalies, 2015; Whitton \& Maclure, 2017). Accordingly, use of videos in learning process leads students to constitute and interpret meaningful mental activities, critical thinking and problem-solving.

Copyright $\odot \mathbf{2 0 2 0}$ by authors; licensee OJCMT. This article is an open access article distributed under the terms and conditions of the Creative Commons Attribution License (http://creativecommons.org/licenses/by/4.0/). 
Furthermore, using videos as instructional materials has positive effects on learning motivation (Schwan \& Riempp, 2004).Videos give the opportunity of realizing real objects, noticing moving sequences and listening the topics (Zhang, Zhou, Briggs, \& Nunamaker, 2006). There are many advantages of using video in education. For example, it increases the persistency in learning and it reduces individual differences among students; it can be used for many years based on it's repeatability;it is economic; it saves time and it can be used in microeducation and easily distributed (Christ, Arya \& Chiu, 2017).

Pekdag (2010) stated that videos are handled as pedagogical tools in education environments.As the third most popular website worldwide and a major web-based video-sharing platform, use of YouTube for educational purposes has increased recently. YouTube is used by educators as a pedagogical resource which aims to teach new knowledge and skills through videos (Prabhu, Vorne, Glaser, Rajagopalan, \& Beriwal, 2017). This resource leads to provide a network with active participation of students in which they support each other in the process of achieving learning objectives and everyone has contribution and value instead of passive learning (Taslibeyaz, 2018).YouTube was a personal video sharing service at the beginning and it has become a website in which people share, watch and comment on the videos in which it is watched by more than 70 millions in a day (Skiba, 2007). According to eBizMBA, the number of estimated unique monthly visitors of YouTube is 1,000,000,000 (eBizMBA, 2017) and it is ranked as the first video sharing site.

When videos are strategically used, they are excellent tools as evidence-based discussion and teaching support. YouTube could be used to constitute a learning group and as a virtual library for to support students' courses through providing access to video clips. Based on the advances of internet technologies, videos can be watched from mobile devices, computers and portable computers in a fast and easy way by millions of people. According to Yildirim and Ozmen (2011); sharing the videos to support lectures, following the instructional videos through forming groups and benefitting from video sharing sites would contribute a great amount of increase in the quality of education. Web 2.0 technologies such as blog, wiki and YouTube has lead to new demands towards learning and provides new supports for learning and teaching. Video sharing sites have emerged based on the idea of sharing moving pictures constituted by people's own opportunities and these sites enable website visitors to search and display of videos throughout the world and become very popular. In regard to these advancements, increase in the use of video sharing sites is observed (Dong \& Goh, 2015; Keskin \& Sayikli, 2017; Kilic \& Celik, 2014).

In the digital platforms of the universities, it is seen that students are also interested in videos as every kind of visual and audio component. Videos are generally prepared within applied lectures by instructors or students. This is regarded as the reflection of student-centered education (Barr, 2018; Birkollu, Yucesoy, Baglama, \& Kanbul, 2017; Savov, Santonova, \& Spassov, 2019). When students prepare videos; this increases social interaction, design, produce and evaluate their products and multi-dimensional recognition of the instructional field at the universities and Pham, Farrell, Vu and Vuong (2017) indicated that YouTube videos are both used for promoting the instructional practices at universities and attracting international students to universities throughout the world. Considering these benefits of the instructional use of Youtube in education and the mentioned positive ourcomes of using Youtube as an instructional tool during university education, it is expected that views of university students on the use of Youtube for educational purposes would extend the perspective in the related field and contribute to the literature. Therefore, this study aims to determine the views of students on the use of Youtube for educational purposes. In line with this general aim, answers to the following questions were also sought in this study:

1. What are the views of teacher candidates on the use of YouTube as an educational material?

2. What are the views of teacher candidates on the lessons in which YouTube is beneficial for teaching?

3. What are the views of teacher candidates on how they can benefit from Youtube to support teaching?

4. What are the views of teacher candidates on the advantages of Youtube as an educational material?

5. What are the views of teacher candidates on the disadvantages of Youtube as an educational material?

6. What are the views of teacher candidates on what can be done for motivating teachers to use YouTube as an educational material?

7. What are the views of teacher candidates on the elements to be considered in the selection of videos in the use of Youtube in education? 
8. What are the views of teacher candidates on the elements to be considered in the selection of videos in the use of Youtube in education?

\section{METHOD}

\section{Research Model}

Qualitative research method was used in the research. Qualitative research data are collected in three ways as open-ended interviews, direct observation and written documents (Platton, 2014). Qualitative research is a type of research in which the events, phenomena, experiences and perceptions of human beings are examined from a holistic point of view and data are obtained and interpreted using different techniques in the light of these aspects (Isikoglu, 2005).

Semi-structured interview technique was used in the study. The most commonly used method in qualitative research is interview technique. The shortest definition of the interview can be described as asking and answering questions. Interview technique is a method that tries to reveal people's thoughts, feelings and perspectives against the events or situations (Yildirim \& Simsek, 2008).

\section{Study Group}

The research was carried out at a private university in Nicosia, North Cyprus. Study group consisted of 14 teacher candidates studying at faculty of education. Ages of teacher candidates participated in the study were between 19 and 28; 10 of them were female and 4 of them were male; 5 of them were second year, 6 of them were third year and 3 of them were fourth year students. The school where the research was applied was determined by appropriate sampling method and the study group were determined by random method.

\section{Data Collection Tool}

As data collection tool, semi-structured interview form prepared by the researchers with the approval of expert opinion was used. In order to learn about the demographic characteristics, age, gender and class levels were asked to the participants. In the interview form, pre-service teachers' thoughts and views about using videos on YouTube as educational material, in which lessons the platform can be useful, advantages and disadvantages of using YouTube for educational purposes, what can be done to encourage the use of YouTube platform as a learning environment. As a result of these questions, it was tried to put forward the views of teacher candidates about the use of Youtube platform for educational purposes.

\section{Procedure}

Before carrying out the interviews, teacher candidates were briefly informed about the aims of the research, the fact that participation is voluntary-based and they can quit from the study if they want. A total number of 8 open-ended questions were asked to the participants in the interview form. There was no time limitation and interviews lasted for approximately 25-30 minutes.

\section{Data Analysis}

The data obtained in the study were interpreted with descriptive and content analysis.Content analysis involves the systematization and categorization of individuals' behaviors and attitudes in a systematic way and tabulating them (Buyukozturk et al., 2016). Descriptive analysis includes the interpretation of the concepts and themes of the data obtained from content analysis (Yildirim \& Simsek, 2008). After the interview with 14 teacher candidates, the data were examined and temporary codes were determined. The identified categories were discussed with 2 field experts and re-shaped after the exchange of ideas. Data that did not conform to the categories were carefully examined. After editing and tabulating the categories, the data were interpreted and presented with tables, frequencies and sample quotations from the answers of the participants. 
Table 1. Views on the use of YouTube as an educational material

\begin{tabular}{cl}
\hline View & $\mathbf{f}$ \\
\hline Appropriate as an educational material & 5 \\
\hline There are informative and effective videos in YouTube. & 4 \\
\hline It should be used deliberatively. & 3 \\
\hline It might be time consuming. & 3 \\
\hline It might be beneficial for learning an unclear subject. & 2 \\
\hline Not appropriate as an educational material & 2 \\
\hline It supports permanence in learning. & 1 \\
\hline It might be distracting for students. & 1 \\
\hline
\end{tabular}

Table 2. Views on the lessons in which YouTube is beneficial for teaching

\begin{tabular}{cl}
\hline View & $\mathbf{f}$ \\
\hline Maths & 4 \\
\hline Turkish & 2 \\
\hline Geography & 2 \\
\hline English & 2 \\
\hline Physics, Chemistry and Biology & 1 \\
\hline Coding & 1 \\
\hline
\end{tabular}

\section{RESULTS}

\section{Teacher Candidates' Views on the Use of YouTube as an Educational Material}

Table 1 shows the results on teacher candidates' views on the use of YouTube as an educational material. As it can be seen, there are 7 different views obtained. In general, 5 teacher candidates stated that they think it is appropraite to use YouTube as an educational material and 2 of them stated that it is not appropriate to use. Teacher candidates participated in the study found YouTube as time consuming, beneficial for learning an unclear subject and distracting for students. They also reported that YouTube should be used deliberatively and supports permanence in learning. Sample quotations from the participants are provided below:

"I think educational videos on YouTube is useful for children and adults. Lesson videos on Youtube are a repetition for a student who doesn't understand the lesson in the classroom and offers an opportunity for him to understand a topic he doesn't understand." (P5)

"The fact that these videos can be used as educational material varies from person to person. Youtube may not be as educational as mentioned. Nowadays, it is seen that people spend time in vain." (P8)

\section{Teacher Candidates' Views on the Lessons in which YouTube is Beneficial for Teaching}

According to Table 2, teacher candidates participated in the study provided 6 different views on the lessons in which they think YouTube is beneficial for teaching. They stated that it is beneficial to use YouTube for teaching Maths, Turkish, Geography, English, Physics, Chemistry and Biology and Coding. Below, there are sample statements from teacher candidates about their views:

"Since Youtube is a video sharing platform, it is more useful to use in subjects and courses that contain more images. For example, in geography lesson, it may be more useful to explain the subject with map display."(P2)

"Youtube can be used in teaching Turkish and Geography." (P7)

\section{Teacher Candidates' Views on How they can Benefit from Youtube to Support Teaching}

Results on the views on how teacher candidates can benefit from Youtube to support teaching are shown in Table 3. As it can be seen, there are 3 different views involving making videos of lessons to ensure permanence, showing videos from YouTube to reinforce learning and not prefer using YouTube to support teaching.

"I will definitely benefit from Youtube to support teaching."(P1)

"Redeemable. Video is taken about the subject to be covered. Students can open and watch these videos as many times as they want. "(P8) 
Table 3. Views on how teacher candidates can benefit from Youtube to support teaching

\begin{tabular}{cl}
\hline View & f \\
\hline Making videos of lessons to ensure permanence & 7 \\
\hline Showing videos from YouTube to reinforce learning & 4 \\
\hline Not prefer using YouTube to support teaching & 1 \\
\hline
\end{tabular}

Table 4. Views on the advantages of Youtube as an educational material

\begin{tabular}{cl}
\hline View & $\mathbf{f}$ \\
\hline Repeating the lesson subjects & 6 \\
\hline Always accessible & 4 \\
\hline Free & 2 \\
\hline Ease of application & 2 \\
\hline
\end{tabular}

Table 5. Views on the disadvantages of Youtube as an educational material

\begin{tabular}{cl}
\hline View & f \\
\hline Addiction to technology & 4 \\
\hline Lack of eye contact & 3 \\
\hline Loss of concentration & 2 \\
\hline Learners can not ask question while watching & 2 \\
\hline Risk of unreferenced knowledge on subjects & 1 \\
\hline Remove students from social environments & 1 \\
\hline No disadvantage & 1 \\
\hline
\end{tabular}

"If there is any lesson, I'll make students watch Youtube video for reinforcement purposes." (P10)

"I don't prefer using Youtube to support teaching because I think I need to make eye contact with the narrator to understand a topic for myself. I prefer to be face to face with my students because I think this is not possible with Youtube." (P11)

\section{Teacher Candidates' Views on the Advantages of Youtube as an Educational Material}

Results on teacher candidates' views on the advantages of Youtube as an educational material are provided in Table 4. "Repeating the lesson", "Always accessible", "Free" and "Ease of application" are the views obtained from this research question. Sample statements from teacher candidates' are as follows:

"A great advantage in terms of repetition. We can also watch for free. It is a great advantage to repeat the lesson that a learner does not understand."(P4)

"Students can use this application wherever they wish. In this case, they will have a chance to listen to the subject of the course they missed." (P11)

\section{Teacher Candidates' Views on the Disadvantages of Youtube as an Educational Material}

According to Table 5, teacher candidates reported 7 different views on the disadvantages of YouTube as en education material. Results showed that addiction to technology, lack of eye contact, loss of concentration, not being able to ask question while watching, risk of unreferenced knowledge on subjects, remove students from social environments, no disadvantage are the views of teacher candidates. There are sample statements on the views provided by the teacher candidates participated in the study:

"In my opinion, as a single disadvantage, it makes students more dependent on technology." (P7)

"Lots of unreferenced knowledge on subjects requiring academic knowledge." (P9)

\section{Teacher Candidates' Views on What can be Done for Motivating Teachers to Use YouTube} as an Educational Material

Results on the views on what can be done for motivating teachers to use YouTube as an educational material are provided in Table 6 . As it can be seen, there are 4 different views obtained from teacher candidates participated in the study. Some sample statements are provided as follows:

"The description of use and safe use can be supported for teachers." (P9) 
Table 6. Views on what can be done for motivating teachers to use YouTube as an educational material

\begin{tabular}{cl}
\hline View & $\mathbf{f}$ \\
\hline Describe how to use for educational purposes & 6 \\
\hline Safe use & 4 \\
\hline Motivate to use as an assistive source & 2 \\
\hline Necessary equipment can be provided & 1 \\
\hline
\end{tabular}

Table 7. Views on the elements to be considered in the selection of videos in the use of Youtube ineducation

\begin{tabular}{cl}
\hline View & $\mathbf{f}$ \\
\hline Appropriate for age level & 9 \\
\hline No ideological ideas & 7 \\
\hline Accuracy of information in the videos & 6 \\
\hline Image quality & 6 \\
\hline Not very long videos & 4 \\
\hline Scientific content & 3 \\
\hline Voice tone & 3 \\
\hline
\end{tabular}

Table 8. Views on the effects of using Youtube as an educational material on students' learning motivations

\begin{tabular}{cl}
\hline View & f \\
\hline Students can develop themselves. & 8 \\
\hline Reinforcements can be used in the videos. & 3 \\
\hline Interesting visuals in the videos & 2 \\
\hline
\end{tabular}

"Video can be taken on any subject. It can be encouraged as it will make things easier as an auxiliary resource." (P12)

\section{Teacher Candidates' Views on the Elements to be Considered in the Selection of Videos in the Use of Youtube in Education}

According to Table 7, there are 7 different views on the elements to be considered in the selection of videos in the use of Youtube ineducation. When the results are examined, it is seen that teacher candidates mostly stated that "appropriate for age level" and "no ideological ideas" are the most frequent reported elements.Sample statements are provided below:

"Image quality should be good." (P1)

"Accurate information should be contained in videos". (P7)

\section{Teacher Candidates' Views on the Effects of Using Youtube as an Educational Material on Students' Learning Motivations}

When the results on the views on the effects of using Youtube as an educational material on students' learning motivations are provided in Table 8. As it can be seen, there are 3 different views obtained. Sample statements from the views of teacher candidates are provided below:

"It ensures motivations for learning the subjects." (P5)

"If there are interesting visuals in the video content, the student's interest in the course may increase." (P8)

\section{DISCUSSION}

Continuous development of technology ensures that all tools used by individuals acquire a more functional quality and plays a role in the provision of new opportunities to learners. Various technological platforms including social networks and video sharing websites have the characteristics of improving the communication skills of students and teachers through expanding participation, strengthening peer support and enabling the realization of cooperative learning (Lepi, 2012). Especially the rapid development in instructional technologies affects the communication habits and life practices of people directly. Youtube Platform offers an environment where people share their thoughts and opinions. This platform also providesopportunities to support the learning process of the students by enriching the learning and teaching 
processes with materials videos (Pollara, \& Zhu, 2011). Regarding these innovations and developments, this study aimed to determine the views of teacher candidates on the use of YouTube for educational purposes.

According to the results of the study, it was determined that majority of teacher candidates think it is appropraite to use YouTube as an educational material. There were contradictory views of teacher candidates on YouTube. Accordingly, Szeto and Cheng (2014) showed that teacher candidates prefer using Youtube as a useful tool for teaching at different school levels.Results of the present study also showed that YouTube is beneficial to use for teaching Maths, Turkish, Geography, English, Physics, Chemistry and Biology and Coding. Lewis and Park (2017) also supported that YouTube videos are effective tools for teaching physical geography.

Furthermore, teacher candidates stated that teachers can use YouTube to ensure permanence and reinforce learning.Being able to repeat the lesson, being accessible, free and easy to use are the advantages expressed by teacher candidates participated in the study. In parallel with these results, Snelson (2018) suggested that YouTube is useful in terms of free video hosting.YouTube has many features and opportunities to help teachers support their teaching and learning processes with active, creative, cooperative learning, and to improve teacher-student interaction and use and develop students' research, inquiry and problem solving skills. It is seen that universities, which set their educational goals on long-term strategies according to current developments, adapt rapidly to the e-learning process in order to take advantage of new media opportunities. Looking at the existing practices, it can be easily predicted that educational videos will play a central role in elearning in the near future (Ata \& Atik, 2016).

On the other hand, addiction to technology, lack of eye contact, loss of concentration, not being able to ask question while watching, risk of unreferenced knowledge on subject and removal of students from social environments are disadvantages of using YouTube in the study. Jalaluddin (2016) also mentioned about other various advantages of YouTube in the class such as privacy, no control, inappropriate contents and no restriction on comments. Results also showed that description of how to use YouTube for educational purposes in a safe way as an assistive source with necessary equipment are essential elements for motivating teachers to use YouTube for educational purposes.

Teacher candidates were also asked about their views on the components when selecting videos and they stated that "appropriate for age level" and "not including ideological ideas"are the most frequent reported elements. When the results on the effects of using YouTube as an educational material on students' learning motivations are considered, it was determined that students' opportunity to develop themselves, reinforcements and interesting visuals in the videos are learning motivations provided by YouTube according to teacher candidates.

In conclusion, this study revealed teacher candidates' views on using YouTube for educational purposes. In line with the results of the study, following recommendations are presented for further research and practices:

- This study was applied to teacher candidates and it could also be applied to middle and high school students.

- Courses informing and motivating students to use YouTube in lessons can be taught in faculties of education.

- Experimental studies can be carried out using YouTube and different variables should be examined.

\section{REFERENCES}

Ata, A., \& Atik, A. (2016). Alternatif bir egitim-ogretim ortami olarak video paylasim siteleri: Universitelerdeki youtube uygulamalari. Social Sciences, 11(4), 312-325. https://doi.org/10.12739/NWSA.2016.11.4.3C0152

Barr, M. (2018). Student attitudes to games-based skills development: Learning from video games in higher education. Computers in Human Behavior, 80, 283-294. https://doi.org/10.1016/j.chb.2017.11.030

Birkollu, S. S., Yucesoy, Y., Baglama, B., \& Kanbul, S. (2017). Investigating the attitudes of pre-service teachers towards technology based on various variables. TEM Journal, 6(3), 578. https://doi.org/10.18421/TEM6320

Buyukozturk, S., Cakmak, E., Akgun, O. E., Karadeniz, S., \& Demirel, F. (2016). Bilimsel arastirma yontemleri. Ankara, Pegem Yayincilik. https://doi.org/10.14527/9789944919289 
Chen, C. M., \& Wu, C. H. (2015). Effects of different video lecture types on sustained attention, emotion, cognitive load, and learning performance. Computers \& Education, 80, 108-121. https://doi.org/10.1016/j.compedu.2014.08.015

Christ, T., Arya, P., \& Chiu, M. M. (2017). Video use in teacher education: An international survey of practices. Teaching and Teacher Education, 63, 22-35. https://doi.org/10.1016/j.tate.2016.12.005

Dong, C., \& Goh, P. S. (2015). Twelve tips for the effective use of videos in medical education. Medical Teacher, 37(2), 140-145. https://doi.org/10.3109/0142159X.2014.943709

eBizMBA. (2017). The most popular video websites. Retrieved on 24 January 2018 from http://www.ebizmba.com/articles/video-websites

Gaudin, C., \& Chalies, S. (2015). Video viewing in teacher education and professional development: A literature review. Educational Research Review, 16, 41-67. https://doi.org/10.1016/j.edurev.2015.06.001

Isikoglu, N. (2005). Egitimde nitel arastirma. Egitim Arastirmalari, 20, 158-165.

Jalaluddin, M. (2016). Using YouTube to Enhance Speaking Skills in ESL classroom. English for Specific Purposes World, 17, 50-54.

Keskin, U., \& Saykili, A. (2017). Video sozluk uygulamalarinin acik ve uzaktan ogrenme materyali olarak kullanimi. Acikogretim Uygulamalari ve Arastirmalari Dergisi, 3(4), 43-61.

Kilic, E., \& Çelik, B. (2014). Dijital video kullaniminin prosedurel ogrenme surecinde kullaniminin teknoloji kabul modeli ile degerlendirilmesi. Ilkogretim Online, 13(3), 980-991.

Lepi, K. (2012). 25 ways teachers can integrate social media into education. [Online]. Retrieved on 14 September 2019 from http://edudemic.com/2012/07/a-teachers-guide-to-social-media/

Lewis, Q. W., \& Park, E. (2018). Volunteered geographic videos in physical geography: data mining from YouTube. Annals of the American Association of Geographers, 108(1), 52-70. https://doi.org/10.1080/24694452.2017.1343658

Mardis, M. A. (2009). Viewing Michigan's digital future: Results of a survey of educators' use of digital video in the USA. Learning, Media and Technology, 34(3), 243-257. https://doi.org/10.1080/17439880903141539

Patton, M. Q. (2014). Qualitative evaluation and research methods: Integrating theory and practice. US: Sage Publications.

Pekdag, B. (2010). Alternative methods in learning Chemistry: Learning with animation, simulation, video and multimedia. Journal of Turkish Science Education, 7(2), 111-118.

Pham, H., Farrell, K., Vu, H., \& Vuong, Q. H. (2017). Using YouTube videos to promote universities: A content analysis. Technics Technologies Education Management (TTEM), 12(1), 58-72.

Pollara, P., \& Zhu, J. (2011, March). Social networking and education: Using Facebook as an edusocial space. In Society for Information Technology \& Teacher Education International Conference (pp. 3330-3338). Association for the Advancement of Computing in Education (AACE).

Prabhu, A. V., Horne, Z., Glaser, S., Rajagopalan, M., \& Beriwal, S. (2017). YouTube as a source of patient information: Assessing quality of information in brachytherapy education videos. Brachytherapy, 16(3), 95-110. https://doi.org/10.1016/j.adro.2019.01.007

Savov, S. A., Antonova, R., \& Spassov, K. (2019). Multimedia applications in education. In Smart Technologies and Innovation for a Sustainable Future (pp. 263-271). Springer, Cham. https://doi.org/10.4108/eai.13-72018.160390

Snelson, C. (2018). The benefits and challenges of YouTube as an educational resource. The Routledge Companion to Media Education, Copyright, and Fair Use, 203-218. https://doi.org/10.4324/978131563754915

Szeto, E., \& Cheng, A. Y. N. (2014). Exploring the usage of ICT and YouTube for teaching: A study of pre-service teachers in Hong Kong. The Asia-Pacific Education Researcher, 23(1), 53-59. https://doi.org/10.1007/s40299-013-0084-y

Taslibeyaz, E. (2018). Ingilizce egitiminde kullanilan senaryo temelli etkilesimli videolara yonelik ogrenci gorusleri. Kastamonu Egitim Dergisi, 26(1), 21-28. https://doi.org/10.24106/kefdergi.374832

Whitton, N., \& Maclure, M. (2017). Video game discourses and implications for game-based education. Discourse: Studies in the Cultural Politics of Education, 38(4), 561-572. https://doi.org/10.1080/01596306.2015.1123222

Yildirim, A., \& Simsek, H. (2008). Sosyal bilimlerde nitel arastirma yontemleri. Ankara: Seckin Yayincilik. 
Yildirim, N., \& Ozmen, B. (2011). The use of video sharing websites for educational purposes. Paper presented at 5th International Computer \& Instructional Technologies Symposium, 22-24 September 2011, Firat University, Elazig - Turkey.

Zhang, D., Zhou, L., Briggs, R. O., \& Nunamaker, J. F. (2006). Instructional video in e-learning: Assessing the impact of interactive video on learning effectiveness. Information \& Management, 43(1), 15-27. https://doi.org/10.1016/j.im.2005.01.004

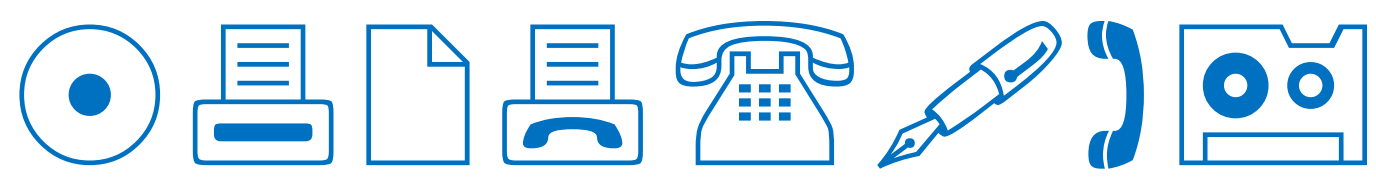

